\title{
On the Vertical Mixing of Sea-Water and its Importance for the Algal Plankton.
}

\author{
By \\ W. R. G. Atkins, O.B.E., Sc.D., F.I.C., \\ Head of the Department of General Physiology at the Plymouth Laboratory.
}

With Figure 1 in the Text.

DURING the last three years determinations of hydrogen ion concentration, temperature, salinity, and phosphates have afforded evidence that sea water is at certain times far from uniform in composition from surface to bottom. Approximate determinations of the respirable organic matter, and the examination of the algal plankton of the water-bottle samples carried out by Dr. M. V. Lebour, have furnished further reasons for regarding the different levels in the sea as more or less distinct localities at certain seasons and under specified conditions. Though attention has from time to time been called to this when discussing the results of the various determinations, yet it seemed of interest to collate and compare them here.

As regards salinity, a difference between top and bottom is taken to denote the inflow either of less saline water on the surface or of more saline water beneath, according to the facts favouring either supposition. As a general rule the area coyered by the cruises from Plymouth exhibits a remarkable uniformity in salinity and an almost absolute uniformity from surface to bottom. There are, however, exceptions, such as those for April 24th and 25th, 1923, for which values of S\%o are given below:-

$\begin{array}{cccc}\text { m. } & \text { E 1 } & \text { E 2 } & \text { E 3 } \\ 0 & 35 \cdot 29 & 34 \cdot 95 & 34 \cdot 67 \\ 15 & 35 \cdot 28 & 34 \cdot 94 & - \\ 25 & - & 35 \cdot 08 & 34 \cdot 86 \\ 50 & 35 \cdot 27 & 35 \cdot 11 & 35 \cdot 01 \\ \text { Bottom } & 35 \cdot 30 & 35 \cdot 16 & 35 \cdot 10\end{array}$

Here an inflow of less saline water on the French side is clearly indicated, but the May results show that complete mixing has taken place, for the salinity gradient no longer exists, save that a slight fresh-water effect had become noticeable down to 5 metres on the English side at E 1.

Similar reasoning led to the supposition that, when abrupt changes NEW SERIES.-VOL, XIII. No. 2. NOVEMbER, 1924. 
in temperature were found in the water column, a different origin was to be sought for the warmer upper layer. The evidence reviewed here is all against this view and in favour of regarding such changes as due to the incidence of radiant heat energy upon a column or sheet of water in which vertical mixing is temporarily in abeyance. Reference to the temperatures recorded in the writer's accompanying paper on hydrogen ion concentration, and in the former papers of the series, Parts I and II, shows how sharp such temperature differences may be in calm summer weather. Some of the 1923 records are plotted in Fig. 1. In

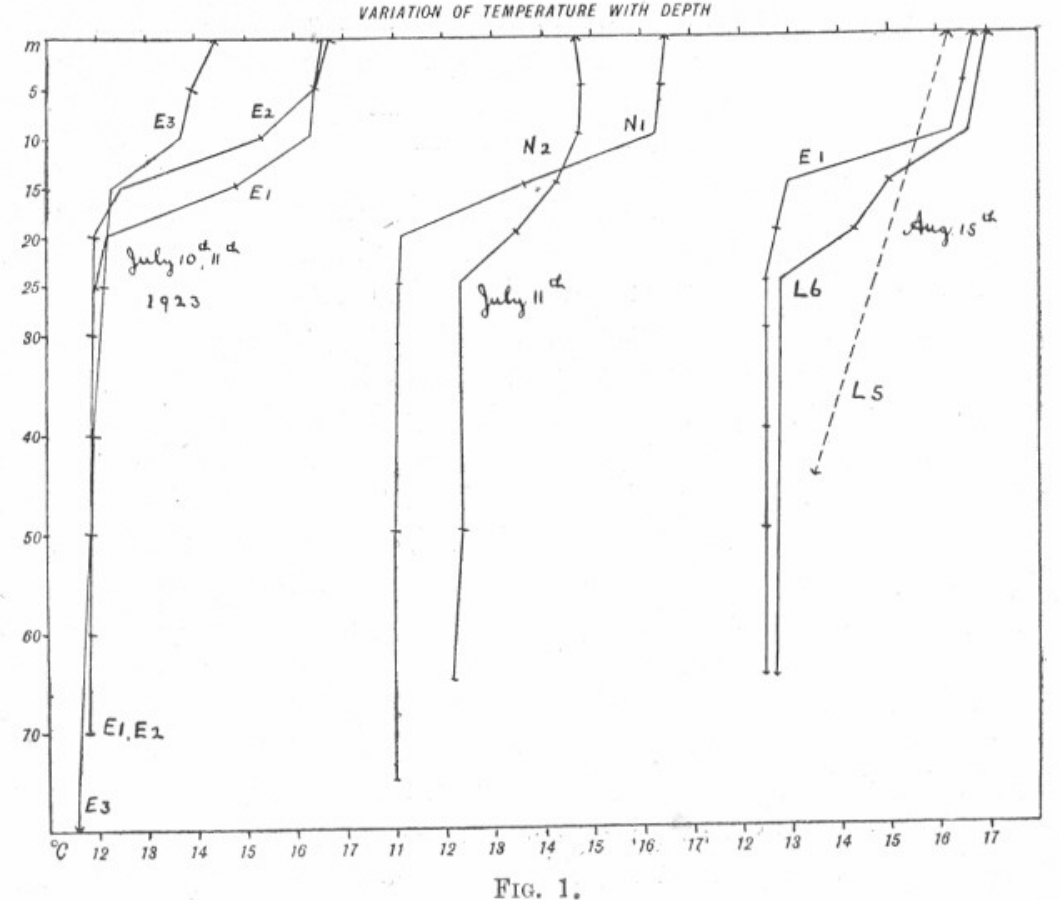

this it may be seen that the gradient is less marked at E 3 than at E 1 or E 2, and is less at N 2 than at N 1 in July. Again, in August a greater amount of mixing, as indicated by the warmer bottom temperature, has taken place at L 5 than at L 6 , and at L 6 than at $\mathrm{E} 1$. The effect of stormy weather is well brought out by the June and July, 1922, records, a drop of $3.3^{\circ}$ between surface and 20 metres on June 6th having been reduced to $0.8^{\circ}$ on July 11 th ; a difference of $2 \cdot 2^{\circ}$ appeared again in August, but from September onwards the temperature gradient throughout the whole column was negligible; this condition was maintained till the following June, and in July the difference amounted to $4 \cdot 4^{\circ}$ between
0 and 20 metres, falling to $4 \cdot 0^{\circ}$ in August and $1.7^{\circ}$ in September, after which uniformity was attained.

Since the warmer water is also the lighter where the salinity is the same, and the density gradient is all the more marked when the bottom water is the more saline, the physical causes of the mixing must be sought. In relatively shallow water wave motion and the to-and-fro streaming of the tides over the irregularities of the bottom are jointly concerned in the mixing. Of these, wave motion is of but little importance in calm weather, but in stormy weather and in deep water it appears to be the sole agent. As the surface water cools and the density of the water column becomes more uniform, it is clear that vertical mixing may be brought about more readily. When the surface water is colder than the bottom water, mixing is automatic.

In the course of a cruise one cannot fail to be struck with the temperature differences found from station to station and with the variations in $\triangle \mathrm{t}$, the difference between top and bottom values. Similar variations may be observed in $\triangle \mathrm{pH}$ and $\triangle \mathrm{P}_{2} \mathrm{O}_{5}$ in mgrms. per cubic metre. Records for the July, 1923, cruise are tabulated here, and temperature and $\mathrm{pH}$ values for the May, 1922, cruise are given in Part II of the hydrogen ion concentration series. In all such runs, save when stormy weather has ensured a general mixing, one is likely to encounter low temperatures at L 2, the Breakwater, at L 5, the Eddystone, at E 3, off Ushant, often at $\mathrm{N} 2$ some miles south of the Scillies, and off the Lizard. The positions of the stations are shown in the map in Part I, this Journal, Vol. 12, p. 754. Low values observed during the night July 10th-11th were not due to rapid surface cooling, but to mixing with deeper water, as shown by the E 3 depth series observations ; furthermore, similar low values were found at $\mathrm{N} 2$, in the afternoon.

\begin{tabular}{|c|c|c|c|c|c|c|c|c|}
\hline $\begin{array}{l}\text { Locality. } \\
\text { and date. }\end{array}$ & Hour. & $\begin{array}{l}\text { Surface. } \\
t^{\circ} \mathrm{C} \text {. }\end{array}$ & $\begin{array}{l}\text { Botton } \\
\mathrm{t}^{\circ} \mathrm{C} .\end{array}$ & $\Delta \mathrm{t}$ & $\Delta \mathrm{pH}$ & $\begin{array}{l}\Delta \mathrm{P}_{2} \mathrm{O}_{5} \\
\text { mgrms } \\
\text { per m }{ }^{3}\end{array}$ & Notes and $c$ & depth to bottom. \\
\hline L 5 , & Noon & $15 \cdot 6$ & $12 \cdot 1$ & $3 \cdot 5$ & 0.05 & 0 & $\begin{array}{l}\text { Slight swell, } \\
46 \text { metres. }\end{array}$ & slightly overcast, \\
\hline & 0.45 p.m. & 16.8 & $11 \cdot 9$ & $4 \cdot 9$ & 0.08 & $\overline{10}$ & $65 \mathrm{~m}$ & \\
\hline $\begin{array}{l}E 1 \\
20 \text { miles on }\end{array}$ & $\begin{array}{l}1.30 \text { p.m. } \\
5.15 \text { p.m. }\end{array}$ & $\begin{array}{l}16 \cdot 6 \\
16 \cdot 8\end{array}$ & $\underline{11 \cdot 9}$ & $\begin{array}{l}4 \cdot 7 \\
-\end{array}$ & $\underline{0.08}$ & 10 & $70 \mathrm{~m}$. & - \\
\hline & 7.30 p.m. & $16 \cdot 7$ & $11 \cdot 8$ & 4.9 & $0 \cdot 08$ & 10 & $85 \mathrm{~m}$. & \\
\hline $20 \mathrm{~m}$. on & 11.30 p.m. & $14 \cdot 8$ & - & - & - & $\overline{10}$ & & - \\
\hline $\begin{array}{l}\text { E } 3 \text {, 11th } \\
24 \text { m. on }\end{array}$ & $\begin{array}{l}3 \text { a.m. } \\
7 \text { a.m. }\end{array}$ & $\begin{array}{l}14 \cdot 5 \\
14 \cdot 5\end{array}$ & $11 \cdot 6$ & $2 \cdot 9$ & $\begin{array}{l}0.08 \\
-\end{array}$ & 16 & $100 \mathrm{~m}$. & \\
\hline 1 & 10.30 a.m. & $16 \cdot 5$ & $11 \cdot 0$ & 5.5 & $0 \cdot 09$ & 20 & Sunny, slight & haze, $100 \mathrm{~m}$. \\
\hline $0 \mathrm{~m}$. on & 3 p.m. & $17 \cdot 4$ & - & - & - & - & & - \\
\hline & 6 p.m. & $14 \cdot 7$ & $12 \cdot 2$ & $2 \cdot 5$ & $0 \cdot 04$ & 5 & Visibility bad, & , fog around, $85 \mathrm{~m}$. \\
\hline & 9.15 p.m. & $15 \cdot 8$ & - & 一 & - & - & Very calm, cle & ear, $70 \mathrm{~m}$. \\
\hline 5,12 th & 10 p.m. & $\begin{array}{l}17.3 \\
16.4\end{array}$ & 二 & $\overline{-}$ & 二 & 二 & Thick fog. & \\
\hline & 0 a.m. & $\begin{array}{l}16.4 \\
16 \cdot 6\end{array}$ & $\overline{12 \cdot 2}$ & $4 \cdot 4$ & $\overline{0.04}$ & $\overline{2}$ & $50 \mathrm{~m}$. & \\
\hline & 7 a.m. & $16 \cdot 7$ & $12 \cdot 7$ & $4 \cdot 0$ & $0 \cdot 05$ & 4 & $45 \mathrm{~m}$. & \\
\hline & - & 15. & $14 \cdot 6$ & $1 \cdot 2$ & $0 \cdot 00$ & - & $14 \mathrm{~m}$. & \\
\hline
\end{tabular}


The abruptness of the temperature change during settled weather is often very remarkable. On account of the vertical motion of the ship it is impossible to define it precisely, but at N 2 in July, 1921, a difference of $2 \cdot 05^{\circ}$ was observed between 27 and 32 metres with $\triangle \mathrm{pH} 0.05$. On August 12th, 1921, $\triangle \mathrm{t}$ was $2 \cdot 12^{\circ}$ between 20 and 25 metres at E 1, and on July 10th, 1923, $\triangle \mathrm{t}$ amounted to $2 \cdot 64^{\circ}$ between 15 and 20 metres, which increased to $3 \cdot 77^{\circ}$ by the 19th; on August 15th the cold-water layer was at 15 metres, and between this and 10 metres $\triangle \mathrm{t}$ was $3 \cdot 32^{\circ}$ and $\triangle \mathrm{pH} 0.04$. On July 10 th $\triangle \mathrm{pH}$ was as great as 0.07 between the depths 15 to 20 metres.

The values for $\triangle \mathrm{t}$ and $\triangle \mathrm{pH}$ are usually maxima over the same range, but on June 19th, 1923, $\triangle \mathrm{pH}$ was 0.07 between 20 and 25 metres, yet $\triangle \mathrm{t}$ was only $1 \cdot 14^{\circ}$; thus high values for $\triangle \mathrm{pH}$ may be met with earlier in the season than for $\triangle t$.

One effect of a high $\mathrm{pH}$ gradient is that in the more alkaline upper layer the partial pressure of carbon dioxide is quite considerably reduced, as explained in Part II previously mentioned. With abundant sunshine it may thus result that the lower partial pressure limits the rate of algal photosynthesis.

Another factor which influences algal growth, and seems to be the limiting factor in the summer, is the quantity of phosphate available. As shown in the last issue of this Journal, pp. 119-150, the phosphate at the surface is used up completely, though a considerable amount of phosphate may still remain in the deeper water. The rate of multiplication of the algal plankton may therefore be greatly influenced by the rapidity with which this is brought to the upper layers into good illumination. Thus the stormy June of 1922 , which so markedly altered the $\mathrm{pH}$ and temperature gradients, must have been equally effective in rendering available the phosphate of the deeper waters. For reasons connected with phosphate supply it is therefore clear that evidence upon the vertical circulation of sea water is one of the most important factors to be considered.

Reference has already been made to Dr. Lebour's examination of the algal plankton of the water-bottle samples. These extended over a period of close on two years, but no evidence was obtained that any particular organism was to be found at one depth rather than at another. During the summer when rapid vertical mixing was in abeyance a certain amount of stratification of the plankton did occur, and phytoplankton is as a rule most abundant in the upper layers. Evidence as regards this has also been obtained by observing the changes in $\mathrm{pH}$ value of the water samples which take place on storing. The change, as explained in this Journal, Vol. 12 , pp. 772-780, is due to the production of carbon dioxide in the water through the breakdown of what has been termed the respirable organic matter. The colour changes which occur in the tubes are striking, and are most marked during summer and autumn, usually in the top 25 to 30 metres; as a rule no two tubes of a depth series give exactly the same final $\mathrm{pH}$ value. However, once the temperature and $\mathrm{pH}$ gradient vanish owing to the vertical mixing of the water all such differences from tube to tube become much less, and the total change during winter is relatively small.

We may conclude that at certain stations irregularities in the bottom suffice to cause a considerable amount of vertical mixing in the water, even during calm weather, so that the gradients in the water brought about either directly or indirectly by incident light and heat energy are much reduced. At other stations such gradients may be very noticeable during settled fair weather. These conditions may be observed from May to August, but by September stormy weather and cooling of the surface water have usually effected much vertical mixing, which is complete by October, so that the water attains and maintains a great degree of uniformity from top to bottom.

Thermal stratification and the marked differences in the dissolved gases which accompany it have been very fully treated of by Birge and Juday, in their "Inland Lakes of Wisconsin," Survey Bull. No. 64, 1922. In these lakes, the largest of which, Mendota, is $9 \cdot 5 \times 7 \cdot 4$ kilometres, with maximum depth $25 \cdot 6$ and mean $12 \cdot 1$ metres, the upper layer or epilimnion varies from 5 to 7 metres when first formed, but it gradually increases in thickness as the season advances, extending to a depth of 10-12 metres by the middle of September. The same authors record in Bull. No. 22, 1911, full details of the manner in which these stratifications originate, through the water immediately next the surface being heated by radiant heat.

In "Notes from the Biological Laboratory of the Wisconsin Geological and Natural History Survey," reprinted from Wisconsin. Acad., Vol. 20, and issued February, 1922, Birge continues Juday's descriptions of the limnological apparatus used, and in particular the electrical pyrlimnometer, which shows how rapidly radiant heat is absorbed by water. Thus, whereas 1.30 calories per sq. cm. per minute were recorded at a depth of $0 \mathrm{~cm}$., at $25 \mathrm{~cm} .0 \cdot 41$ calories was received, at $200 \mathrm{~cm}$. only $0 \cdot 20$, at $400 \mathrm{~cm} \cdot 0 \cdot 10$, and at 10 metres $0 \cdot 013$. The homogeneity of the upper 10 metres of the sea as regards temperature can therefore only be brought about by the mixing of the surface water, which is efficient to a depth depending upon the length of the waves from crest to crest, and beyond that but little mixing appears to occur. The writer's own experience has shown that in the still water of a large pond the surface-about $2 \mathrm{~cm}$. may be as many as $5^{\circ} \mathrm{C}$. warmer than the water at $20 \mathrm{~cm}$.

The data accumulated by Birge and Juday are most valuable and find 
application in the study of marine problems also. They appear to support the view that the stratification observed in the waters of the English Channel has arisen at each station where found, except in so far as the tidal movement may have affected it.

\section{SUMMARY.}

1. Measurements of hydrogen ion concentration, of phosphate concentration, and of temperature all show at certain seasons a well-marked gradient from surface to bottom. The upper 10-20 metres is more alkaline, notably depleted of phosphates and warmer.

2. Settled summer weather and deep water, free from irregularities of the bottom, favour the formation of such a gradient. Its breaking up is occasioned by wave action and the cooling of the surface water in autumn.

3. Thermal stratification in the English Channel arises at each station, and is not due to the inflow of warm over colder water. 